\title{
PENINGKATAN PENGUASAAN KOSAKATA BAHASA INGGRIS MELALUI MEDIA ANAGRAM DALAM METODE KOOPERATIF TIPE TEAMS GAMES TOURNAMENT
}

\section{IMPROVING THE ENGLISH VOCABULARY MASTERY \\ THROUGH ANAGRAM MEDIA IN COOPERATIVE METHODS OF STUDY TEAMS GAMES TOURNAMENT TYPE}

\author{
Hengki Yudha Barnaba, Asruddin Barori Tou \\ - , Universitas Negeri Yogyakarta \\ pakdebarna@yahoo.com; asruddintou@yahoo.com
}

\begin{abstract}
Abstrak
Penelitian ini bertujuan untuk meningkatkan penguasaan kosakata bahasa Inggris siswa kelas IV SDN Sagan Yogyakarta menggunakan media anagram dalam metode pembelajaran kooperatif tipe Teams Games Tournament (TGT). Penelitian ini merupakan penelitian tindakan kelas yang dilaksanakan dalam dua siklus. Subjek penelitian ini adalah siswa kelas IV yang berjumlah 25 orang. Jenis tindakan yang diterapkan adalah media anagram dalam metode pembelajaran kooperatif tipe $T G T$. Tindakan dilaksanakan dalam empat tahapan yaitu, tahap presentasi kelas, tahap diskusi kelompok, tahap permainan turnamen, dan yang terakhir tahap penghargaan kelompok. Pengumpulan data dilakukan melalui observasi, tes hasil belajar, dan analisis dokumen. Hasil penelitian menunjukkan bahwa penerapan media anagram dalam metode pembelajaran kooperatif tipe $T G T$ dapat meningkatkan penguasaan kosakata siswa kelas IV SD Negeri Sagan Yogyakarta.
\end{abstract}

Kata kunci: penguasaan kosakata, media anagram, pembelajaran kooperatif, Teams Games Tournament.

\begin{abstract}
This study aims to improve the English vocabulary mastery of year four student of SD Negeri Sagan Yogyakarta through anagram media in cooperative learning methods of Teams Games Tournament (TGT) type.This research is classroom action research conducted in two cycles. The subject were 25 fourth grade student. The kind of the intervention implemented was anagram media in cooperative learning method of TGT type. The actions implemented in four stages, Teach, Team study, tournament, and team recognition. The data collection was conducted through observation, test, and document analysis. The results show that the application of the anagram media in the cooperative learning method of TGT type can improve the English vocabulary mastery of fourth grade students of Elementary School Sagan Yogyakarta.
\end{abstract}

Keywords: mastery of english vocabulary, anagram media, Cooperative Learning, Teams Games Tournament. 


\section{Pendahuluan}

Bahasa merupakan hal yang penting untuk dikuasai oleh anak, karena semua ide, konsep dan angan-angan disalurkan melalui bahasa. Adakalanya seorang anak yang pandai dan penuh dengan ide-ide cemerlang harus terhenti hanya karena dia tidak bisa menyampaikan idenya dalam bahasa yang baik. Bahasa yang baik adalah bahasa yang digunakan sesuai dengan situasi dan keadaan.

Bahasa juga merupakan penunjang keberhasilan dalam mempelajari semua bidang studi, oleh karena itu pembelajaran bahasa dirasakan perlu diberikan semenjak dini, tentu tujuannya agar anak mampu menggunakan bahasa dengan baik dan benar dan mampu mengkomunikasikan apa yang dirasakannya secara baik. Belajar berbahasa bagi anak usia dini sangat penting untuk pencapaian perkembangan kecerdasan berbahasa di masa yang akan datang. Salah satu pembelajaran bahasa yang tentunya sangat berguna bagi anak baik untuk saat ini dan dimasa mendatang adalah belajar bahasa Inggris. Pembelajaran bahasa Inggris disekolah dasar diajarkan kepada siswa sebagai kegiatan kurikuler untuk mengembangkan keterampilan berbahasa. Keterampilan berbahasa Inggris tersebut mencakup keterampilan mendengar, berbicara, menulis, dan membaca.

Tarigan (2011, p.2) menyakatan bahwa kualitas berbahasa seseorang tergantung pada kualitas kosakata yang dimiliki. Makin kaya kosakakata yang dimiliki makin besar pula kemungkinan terampil berbahasa. Pernyataan Tarigan tersebut menjelaskan bahwa kosakata memegang peranan yang penting dalam berbahasa, baik sebagai penyalur gagasan secara tertulis maupun berbahasa sebagai penyalur gagasan secara lisan.

Para ahli bahasa dalam mendefinisikan tentang pengertian kosakata berbeda-beda, tetapi mereka sepakat bahwa kosakata merupakan alat utama yang harus dimiliki seseorang dalam belajar bahasa. Sebab kosakata adalah perbendaharaan kata atau sejumlah kata yang dimiliki seseorang, semakin kaya kosakata seseorang semakin besar kemungkinan seseorang untuk terampil berbahasa dan semakin mudah pula ia menyampaikan dan menerima informasi baik secara lisan, tulisan, maupun menggunakan tanda-tanda dan isyarat. Pada prinsipnya kosakata dipelajari siswa bertujuan untuk dapat meningkatkan pertumbuhan kegiatan menyimak, berbicara, membaca, dan menulis dengan baik.
Oleh karena itu, siswa membutuhkan suatu sistem atau strategi untuk menerima, menyimpan, dan memunculkan kembali kosakata itu setiap saat.

Berdasarkan praobservasi selama 4 minggu di kelas IV SD Negeri Sagan Yogyakarta, didapati bahwa pembelajaran bahasa Inggris secara umum di kelas tersebut masih menggunakan pendekatan konvensional, yaitu dimana guru lebih banyak mendominasi kegiatan pembelajaran (kegiatan pembelajaran berpusat pada guru), dan ketuntasan belajar siswa diukur dari selesainya siswa mengerjakan LKS. Guru terbiasa menggunakan metode yang sama dalam menyampaikan materi pelajaran, sehingga penyampaian pembelajaranpun kurang menarik bagi siswa, begitu pula dalam pelajaran pengembangan berbahasa khususnya dalam meningkatkan kemampuan kosakata bahasa Inggris masih terlihat kaku, siswa cenderung tidak bersemangat dalam belajar. Hal ini dapat teramati bahwa perilaku siswa memperlihatkan sikap acuh tak acuh terhadap proses pembelajaran, adanya perilaku melamun, mengantuk, dan berbicara dengan teman sewaktu guru menjelaskan di depan kelas.

Permasalahan lain yang ditemukan di lapangan adalah bahwa siswa kelas IV masih senang bermain dan ketika guru menjelaskan didepan kelas beberapa siswa terlihat acuh dan sibuk dengan kegiatannya sendiri. Selain itu peneliti mendapatkan sebagian besar siswa masih terlihat bingung ketika dalam penulisan kosakata. Siswa yang tahu bunyi dan makna dari satu kata belum tentu tahu bagaimana penulisan kata yang benar. Contohnya pada kata "table" beberapa siswa menulis sesuai dengan bunyinya, yakni menjadi "teabel", atau kata "like" ditulis menjadi "laik".

Dalam upaya meningkatkan penguasaan kosakata bahasa Inggris siswa kelas IV SD Sagan Yogyakarta, peneliti menerapkan metode pembelajaran kooperatif tipe Teams Games Tournament (TGT). TGT merupakan salah satu metode yang ditawarkan dalam pembelajaran kooperatif yang menekankan pada bekerja sama untuk mencapai tujuan bersama. Johnson \& Johnson (2002, p.20)

Proses pembelajaran $T G T$ dilakukan secara berkelompok, dimana setiap kelompok terdiri dari 4 (empat) sampai 5 (lima) orang siswa yang memiliki kemampuan, latar belakang, dan gender yang berbeda. Adapun komponen atau tahapan dari pembelajaran kooperatif tipe $T G T$ adalah sebaga berikut: Presentase kelas, 
belajar kelompok, permainan, turnamen, dan penghargaan kelompok. Slavin (1995, p.87)

Dalam penelitian ini peneliti akan meningkatkan penguasaan kosakata bahasa Inggris siswa kelas IV SD Negeri Sagan Yogyakarta dengan menerapkan media anagram dalam pembelajaran kooperatif tipe $T G T$. Dipilihnya anagram sebagai media pembelajaran di karenakan media anagram merupakan permainan kartu dan permainan menyusun kata yang dimainkan secara perorangan maupun kelompok.

Kridalaksana (2008, p.56) mengemukakan bahwa anagram adalah kata atau kelompok kata yang disusun dengan huruf yang sama dari kata atau kelompok kata yang lain. Nurhadi (1995, p.131) mengatakan anagram merupakan suatu pengajaran kosakata yang dilakukan dengan cara pembelajar diminta untuk mengubah urutan huruf-huruf suatu kata sehingga membentuk kata lain. Lebih lanjut Tarigan (1986, p.256). Mencontohkan dari kata kain dapat dibentuk menjadi kata kina, naik, dan ikan. Dari kata gula dapat dibentuk kata lagu, gaul dan agul.

Contoh:

$\begin{array}{llll}\text { Kain } & \text { Kina } & \text { Gula } & \text { Galu } \\ \text { Naik } & & & \text { Gaul } \\ \text { Ikan } & & & \text { Agul }\end{array}$

Dari contoh di atas juga dapat dilihat mobilitas huruf yang dapat dibentuk dalam permainan anagram. Mobilitas huruf yang dapat dibentuk dapat berjumlah satu buah atau lebih. Anagram sangat menarik untuk diterapkan sebagai salah satu teknik pembelajaran bahasa, karena anagram merupakan salah satu jenis permainan. Permainan anagram dapat membangkitkan kreativitas anak. Anak berusaha kreatif mengerjakan huruf-huruf untuk mencari dan menentukan kata-kata yang baru. Kesalahan anak ketika melakukan permainan anagram menjadi pelajaran berharga bagi anak. Pencarian dan penemuan kata baru tersebut dengan sendirinya akan diklasifikasikan oleh anak-anak dengan cara dapat membedakan kata yang bermakna dan tidak. Di samping itu anak akan diperkaya dengan kata-kata yang belum dikuasai sebelumnya.

Metode kooperatif tipe TGT menggunakan media anagram dirasa mampu untuk memecahkan permasalahan yang ada di kelas IV SD Negeri Sagan Yogyakarta karena TGT merupakan metode yang disertai permainan, menurut Blachowicz and Fisher (1996, p.7) pembelajaran kosakata terjadi ketika siswa aktif dalam menemukan bagaimana kata-kata yang berkaitan dengan pengalaman dan satu sama lain. Maka penerapan media anagram dalam metode kooperatif tipe $T G T$ dirasa tepat untuk meningkatkan penguasaan kosakata bahasa Inggris.

Dengan memperhatikan kajian teori dan kerangka berpikir di atas dan kaitannya dengan permasalahan yang ada, hipotesis tindakan yang diajukan adalah penggunaan media anagram dalam metode pembelajaran kooperatif tipe Teams Games Tournament dapat meningkatkan penguasaan kosakata bahasa Inggris siswa kelas IV SD Negeri Sagan Yogyakarta.

\section{Metode}

Penelitian ini merupakan Classroom Action Research (CAR) atau dalam bahasa Indonesia dikenal dengan Penelitian Tindakan Kelas (PTK), yakni suatu pencermatan terhadap kegiatan belajar berupa tindakan yang berfokus pada upaya untuk mengubah kondisi rill sekarang kearah kondisi yang diharapkan (improvement oriented). Penelitian tindakan ini dilakukan dengan tujuan untuk meningkatkan penguasaan kosakata bahasa Inggris melalui model pembelajaran kooperatif tipe $T G T$ dengan menggunakan media anagram. Penelitian ini dilakukan melalui kolaborasi para pelaku dalam proses pembelajaran, yakni guru yang mengajar bahasa Inggris, para siswa dan subjek lain yang terkait seperti kepala sekolah dan teman sejawat.

Dalam penelitian ini, pelaksana atau pengajar adalah guru bahasa Inggris kelas IV yaitu ibu Tri Hartanti, S.Pd, dan peneliti sebagai observer bekerjasama dan membantu menyiapkan media pembelajaran, membuat Rencana Pelaksanaan Pembelajaran (RPP), membuat perlengkapan pembelajaran dan membantu dalam proses pembelajaran. Peneliti dan kolaborator mengamati dan mencatat secara cermat dan sistematik tentang berbagai aspek situasi yang terjadi dalam proses belajar mengajar.

Penelitian tindakan kelas dilakukan melalui proses perencanaan (planning), tindakan (acting), observasi (observing), serta reflesi (reflecting). Desain dalam penelitian ini berdasarkan pada tujuan memberikan tindakan agar dapat menganalisis keadaan dan melihat kesenjangan antara keadaan yang nyata dan keadaan yang diinginkan dan merumuskan rencana tindakan. Dalam proses penelitian ini dipilih model spiral atau siklus menurut Kemmis dan 
Taggart yaitu berupa perangkat-perangkat siklus tindakan dimana satu perangkat terdiri dari tiga tahapan yaitu; perencanaan (planning), tindakan (acting) dan observasi (observing), serta reflesi (reflecting). Ketiga komponen yang berupa untaian tersebut dipandang sebagai satu siklus. Siklus tersebut diartikan sebagai suatu putaran kegiatan yang terdiri dari tahapantahapan, sebagaimana dalam gambar berikut ini:

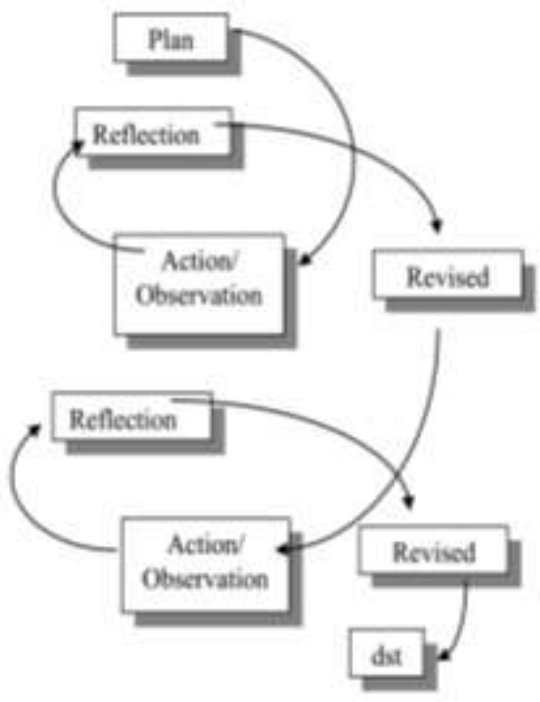

Gambar 1.Tahapan pada Siklus Penelitian

Tindakan Kelas menurut Kemmis \& McTaggart

\section{Waktu Penelitian}

Waktu Penelitian Penelitian ini dilaksanakan pada semester II (dua) tahun ajaran 2012/ 2013 bulan Januari sampai dengan awal Juni 2013. Penelitian ini dimulai dengan observasi awal untuk mendapatkan gambaran yang jelas mengenai keadaan lapangan dengan segala permasalahannya. Selanjutnya dilakukan penelitian lapangan dan menyusun laporan penelitian. Serangkaian dari keseluruhan jenis kegiatan penelitian tersebut meliputi kegiatan observasi awal, penyusunan proposal, seminar proposal, penyusunan instrumen penelitian, validasi instrumen penelitian, pengurusan izin penelitian, pengumpulan data, analisis data, dan penulisan laporan penelitian

\section{Subjek dan Karakteristiknya}

Subjek dalam penelitian ini adalah siswa-siswi kelas IV SD Negeri Sagan Yogyakarta, yang berjumlah 25 murid yang terdiri dari 10 orang murid laki-laki dan 15 orang murid perempuan. Fokus penelitian ini adalah penguasaan kosakata bahasa Inggris.
Rencana Tindakan

Rencana tindakan yang dilakukan pada penelitian ini adalah penerapan media anagram dalam model pembelajaran kooperatif tipe $T G T$ pada mata pelajaran bahasa Inggris di kelas IV SD Negeri Sagan Yogyakarta tahun ajaran 2012/2013 untuk meningkatkan penguasaan kosakata bahasa Inggris anak. Penelitian ini dilaksanakan dengan mengikuti alur penelitian tindakan kelas berdasarkan model siklus penelitian tindakan kelas menurut Kemmis \& Taggart, maka langkah-langkah penelitian dibagi dalam tiga tahap, yaitu:

\section{Perencanaan (Planning)}

Kegiatan yang dilakukan pada tahap perencanaan adalah mengembangkan fokus penelitian yang diawali dengan menyusun alur pembelajaran, menyusun Rencana Pelaksanaan Pembelajaran (RPP), menyiapkan lembar observasi, menyiapkan soal tes, dan menyiapkan media pembelajaran yang akan digunakan dalam pembelajaran. Adapun rencana tindakan yang dilakukan dalam penelitian ini adalah: (a) Berdiskusi dengan guru bidang studi tentang model pembelajaran kooperatif tipe $T G T$ dan langkahlangkah pelaksanaan pembelajaran dengan menggunakan tipe $T G T$; (b) Berdiskusi dengan guru bidang studi tentang media permainan anagram dan teknik penggunaannya; (c) Berdiskusi dengan guru untuk membuat jadwal pelaksanaan tindakan yang dimulai dari pra survey sampai selesai; (d) Membuat RPP, LKS, lembar obsevasi, dan tes; (e) Memvalidasi instrumen kepada dosen ahli; (f) Menyampaikan pengarahan dan rambu-rambu kepada guru kelas sebagai praktisi agar dalam melaksanakan tindakan sesuai dengan langkah-langkah yang ada didalam model $T G T$.

\section{Pelaksanaan (Action) dan Observasi (observing)}

Pelaksanaan tindakan pada dasarnya disesuaikan dengan setting tindakan yang telah ditetapkan dalam perencanaan. Tindakan yang dilakukan didasarkan pada perencanaan yang telah disusun sesuai dengan permasalahan. Pelaksanaan tindakan bersifat fleksibel dan terbuka terhadap perubahan-perubahan. Guru kelas sebagai kolaborator bertindak sebagai pelaksana tindakan. Sedangkan peneliti sebagai pengamat dibantu oleh seorang rekan sejawat. Pada saat tindakan berlangsung, peneliti dengan dibantu teman sejawat melakukan observasi 
dengan menggunakan instrumen observasi guru dan instrumen observasi siswa yang telah disiapkan. Pengamatan dilakukan dengan menggunakan instrumen yang telah disiapkan. Pengamatan dilakukan dengan cermat dari awal hingga akhir tindakan berlangsung. Dalam mengobservasi peneliti dan kolaborator harus mendapatkan data yang sesungguhnya, peneliti dan kolaborator mencatat hal-hal yang terjadi pada saat pembelajaran berlangsung. Pada tahap pelaksanaan tindakan, peran penelti adalah: (a) Merancang teknik yang akan digunakan dalam pembelajaran; (b) Bekerja sama dengan guru dalam pelaksanaan tindakan; (c) Peneliti berperan sebagai pendamping guru dalam kegiatan pembelajran untuk memberikan pengarahan, motivasi, dan stimulus, agar praktisi dapat melaksanakan perannya berdasarkan rencana yang telah disepakati.

Perencanaan dan tindakan yang dilakukan pada setiap siklus dengan menggunakan media permainan anagram dalam teknik $T G T$ diharapkan dapat memberikan perubahan dalam pelaksanaan pembelajaran dikelas yang nantinya akan memberi peningkatan pada penguasaan kosakata dan hasil belajar bahasa Inggris siswa.

\section{Refleksi (Reflection)}

Pada tahap ini, hasil observasi dan permasalahan yang ada dalam pembelajaran dianalisis dan didiskusikan bersama guru kelas. Tahap refleksi ini merupakan evaluasi terhadap pelaksanaan tindakan yang telah dilaksanakan, apakah dalam proses pembelajaran yang telah dilakukan sesuai dengan yang diharapkan serta kendala yang dihadapi selama proses pembelajaran. Berdasarkan hasil refleksi peneliti dapat melakukan perbaikan terhadap rencana awal yang telah dibuatnya, jika pembelajaran pada siklus sebelumnya kurang berhasil maka akan dilanjutkan pada siklus berikutnya. Kekurangan yang ditemui pada siklus sebelumnya digunakan sebagai dasar penyusunan rencana tindakan pada siklus berikutnya. Demikian seterusnya, sehingga siklus berikutnya akan berjalan lebih baik dari pada siklus sebelumnya.

\section{Teknik Pengumpulan Data}

Data utama yang dikumpulkan dalam penelitian ini adalah proses pembelajaran dengan tipe $T G T$ dengan menggunakan media anagram dalam pembelajaran bahasa Inggris untuk meningkatkan penguasaan kosakata siswa. Dalam penelitian tindakan kelas ini peneliti menggunakan teknik pengumpulan data berupa: observasi, tes, dan dokumentasi.

\section{Observasi}

Observasi merupakan kegiatan untuk mengenali setiap gejala dan indikator dari proses dan hasil yang dicapai, baik yang ditimbulkan oleh tindakan maupun akibat sampingannya. Jenis observasi dalam penelitian ini adalah observasi sistematis, yaitu observasi yang dilakukan pengamat dengan menggunakan pedoman sebagai instrument pengamatan. Observasi dilakukan sebelum dan selama proses pelaksanaan tindakan. Observasi dilakukan dengan menggunakan lembar observasi yang telah divalidasi sebelumnya. Peneliti dibantu oleh kolabator dalam hal ini teman sejawat melakukan pengamatan dan pencatatan secara sistematis terhadap kejadian pada saat tindakan dilaksanakan yaitu meliputi; (a) Tindakan/kegiatan yang dilakukan guru. Tindakan ini meliputi proses pembelajaran yang dilakukan guru berdasarkan model kooperatif tipe $T G T$; (b) Tindakan/kegiatan yang dilakukan siswa. Tindakan ini meliputi aktivitas siswa selama proses pembelajaran bahasa Inggris dengan menggunakan media anagram dalam metode kooperatif tipe $T G T$.

\section{Tes}

Teknik ini digunakan untuk mengukur hasil belajar bahasa Inggris siswa kelas IV SD Negeri Sagan, khususnya mengenai penguasaan kosakata bahasa Inggris yang diajarkan dengan menggunakan media permainan anagram pada teknik pembelajaran kooperatif tipe TGT. Adapun teknik tes yang digunakan pada penelitian ini adalah tes subjektif, yang mengacu kepada pendapat Djiwandono (2011, p.129) yang mengatakan bahwa tes penguasaan kosakata aktifproduktif seharusnya menggunakan tes subjektif.

\section{Dokumentasi}

Teknik dokumentasi digunakan sebagi teknik pengumpulan data dengan jalan melihat dan mempelajari dokumen-dokumen yang berkaitan dengan kegiatan pembelajaran dengan model pembelajaran kooperatif $T G T$. Teknik ini dilakukan untuk memperkuat data yang diperoleh dalam observasi. Dokumentasi juga dilakukan dengan cara pengambilan foto pada proses pembelajaran berlangsung. Siswa di ambil fotonya saat melakukan kegiatan-kegiatan sela- 
ma proses pembelajaran dan pengumpulan hasil tes yang telah digunakan.

\section{Instrumen Penelitian}

Setelah menentukan teknik yang akan digunakan dalam pengumpulan data penelitian, tahap selanjutnya peneliti menyusun instrumen penelitian. Instrumen Penelitian merupakan alat bantu yang digunakan untuk mengumpulkan data. Adapun instrumen dalam penelitian ini adalah sebagai berikut:

\section{Pedoman Observasi}

Observasi dalam penelitian ini adalah observasi langsung yaitu peneliti, rekan sejawat dan guru kelas IV melihat dan mengamati secara langsung, kemudian mencatat perilaku siswa sesuai dengan keadaan sebenarnya. Observasi dilakukan selama proses pembelajaran dari kegiatan awal sampai kegiatan akhir.

\section{Soal Tes}

Tes hasil belajar ini diujikan pada setiap akhir siklus. Tes digunakan untuk mengukur keberhasilan siswa terutama peningkatan penguasaan kosakata bahasa Inggris. Tes hasil belajar yang digunakan adalah tes yang sudah divalidasi oleh dosen ahli dan praktisi. Adapun penyusunan tes hasil belajar didasarkan pada standar kompetensi dan kompetensi dasar yang berlaku di kelas IV SD Negeri Sagan Yogyakarta.

Dalam membuat kisi-kisi tes, peneliti menggunakan taksonomi tujuan pendidikan menurut Bloom (Sanjaya, 2010, p.128), yaitu ranah kognitif. Ranah kognitif adalah kemampuan berpikir, kompetensi memperoleh pengetahuan, pengenalan, pemahaman, konseptualisasi, penentuan dan penalaran. Ranah kognitif yang digunakan meliputi: (a) Pengetahuan (CI), Pada tingkat pengetahuan, siswa menjawab pertanyaan berdasarkan hafalan saja; (b) Pemahaman (C2), Pada tingkat pemahaman, siswa dituntut untuk menyatakan masalah dengan kata-katanya sendiri, memberi contoh suatu prinsip atau contoh; (c) Aplikasi (C3), Pada tingkat aplikasi siswa dituntut untuk menerapkan prinsip dan konsep dalam suatu situasi yang baru.

\section{Teknik Analisis Data}

Data yang sudah dikumpulkan kemudian dianalisis dengan menggunakan analisis kuantitatif dan kualitatif. Analisis data secara kuantitatif yang digunakan dalam penelitian ini yaitu pada perhitungan rerata hasil tes siswa dan disajikan dalam bentuk tabel dan grafik. Data kuantitatif merupakan informasi yang muncul di lapangan yang dapat ditampilkan dalam bentuk angka. Data yang terkumpul dari penelitian ini berupa nilai tes hasil belajar siswa setiap siklus dengan mencari rerata (mean). Analisis data secara kualitatif digunakan untuk mengetahui secara kualitatif hasil penelitian tindakan yang dilakukan. Analisis data dimulai sejak awal sampai akhir pengumpulan data. Adapun hasil analisis tersebut diuraikan dengan kalimat-kalimat yang berbentuk deskriptif kualitatif. Analisis data pada penelitian ini adalah sebagai berikut:

\section{Analisis Hasil Observasi}

Observasi dalam penelitian ini untuk mengetahui aktivitas selama proses pembelajaran. Pernyataan dalam lembar observasi memunyai rerata nilai skor dari skor 0 (nol) dan skor 1 (satu). Apabila observer dalam hal ini peneliti dan teman sejawat memberikan ceklist $(\sqrt{ })$ pada kolom 0 (nol) maka itu berati tidak baik atau tidak terlaksana, jika memberikan ceklist $(\sqrt{ })$ pada kolom 1 (satu) berati baik atau terlaksana. Jumlah skor yang diperoleh pada lembar observasi dijumlahkan, kemudian dianalisis dengan menggunakan rumus sebagai berikut;

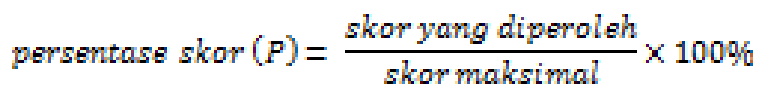

Tabel 1. Kualifikasi Persentase Skor Hasil Observasi

\begin{tabular}{cc}
\hline Rentang Skor & Kualifikasi \\
\hline $80,01 \%-100 \%$ & Sangat Tinggi \\
$60,01 \%-80 \%$ & Tinggi \\
$40,01 \%-60 \%$ & Sedang \\
$20,01 \%-40 \%$ & Rendah \\
$0 \%-20 \%$ & Sangat Rendah \\
\hline
\end{tabular}

Analisis Hasil Tes

Hasil tes yang telah diperoleh dari siswa dianalisis secara kuantitatif untuk mengolah data yang diperoleh dari hasil uji tes yang digunakan untuk mengetahui seberapa besar peningkatan penguasaan bahasa Inggris pada siswa kelas IV SD Negeri Sagan dibuktikan dengan peningkatan hasil evaluasi yang dilaksanakan sebanyak siklus yang dilakukan. 
Nilai yang diperoleh siswa dari hasil tes kemudian dicari reratanya dan dianalisis untuk mengetahui ada atau tidaknya peningkatan penguasaan bahasa Inggris pada siswa kelas IV setelah menggunakan model pembelajaran kooperatif TGT. Adapun cara mengetahui peningkatan penguasaan bahasa Inggris siswa adalah dengan menghitung rerata nilai siswa yang berhasil memperoleh nilai KKM (Kriteria Ketuntasan Minimal) dari jumlah kelas. Adapun ketuntansan minimal SD Negeri Sagan adalah sebagai berikut:

Tabel 2. Standar Ketuntasan Minimum Mata Pelajaran B. Inggris SD N Sagan

\begin{tabular}{ccc}
\hline No & Standar Nilai & Kategori \\
\hline 1 & $70-100$ & Tuntas \\
2 & $0-69$ & Tidak Tuntas/Remedial \\
\hline
\end{tabular}

Untuk mencari perhitungan rerata secara klasikal dari sekumpulan nilai yang telah diperoleh siswa tersebut, peneliti menggunakan rumus mean $(\bar{x})$ sebagai berikut:

$$
\bar{x}=\frac{\sum X}{N}
$$

\section{Keterangan}

$\bar{x}=$ Mean (nilai rata-rata).

$\sum \mathrm{x}=$ Jumlah nilai total yang diperoleh dari penjumlahan nilai setiap hasil individu.

$\mathrm{N}$ = Banyaknya siswa.

Penguasaan kosakata siswa dikatakan meningkat apabila terdapat peningkatan ratarata nilai dari nilai hasil evaluasi sebelumnya. Apabila jumlah nilai rata-rata yang diperoleh seluruh siswa mencapai $70 \%$ ke atas, maka dikatakan penguasaan kosakata bahasa Inggris siswa meningkat. Dan untuk menghitung presentase keberhasilan siswa secara individual dianalisis dengan menggunakan rumus sebagai berikut :

$$
P=\frac{F}{N} x 100 \%
$$

Keterangan

$$
\mathrm{P} \quad=\text { Angka presentase }
$$

$\mathrm{F} \quad=$ Frekuensi yang sedang dicari presentasinya (dalam hal ini adalah jumlah siswa yang mencapai KKM).

$\mathrm{N}$ = Jumlah frekuensi atau banyaknya individu dalam subjek penelitian (dalam hal ini adalah jumlah siswa sebagai subjek penelitian yaitu siswa kelas IV SD Negeri Sagan).

\section{Kriteria Keberhasilan}

Kriteria keberhasilan ini dibagi menjadi dua yaitu, secara kualitatif dan kuantitatif. Indikatornya meliputi: (1) Proses pembelajaran dengan media anagram dikatakan berhasil jika guru telah melaksanakan pembelajaran dengan baik sesuai dengan langkah-langkah metode pembelajaran tipe TGT; (2) Dari segi proses pembelajaran, dikategorikan berhasil apabila terdapat peningkatan aktivitas mengajar guru dan aktivitas belajar siswa dalam proses pembelajaran. Secara kuantitatif, minimal 90\% dari aktivitas mengajar guru telah sesuai dengan langkah-langkah metode pembelajaran tipe TGT; (3) Adanya peningkatan hasil belajar Bahasa Inggris khususnya pada penguasaan kosakata dengan pencapaian ketuntasan minimal 90\% dari julah siswa kelas IV telah memeroleh nilai minimal 70 secara perorangan. Hal ini berdasarkan KKM SD Negeri Sagan Yogyakarta.

\section{Hasil Penelitian dan Pembahasan}

Penelitian ini berangkat dari permasalahan masih rendahnya penguasaan kosakata bahasa Inggris siswa kelas IV SD Negeri Sagan Yogyakarta. Indikasi munculnya permasalahan ini disebabkan karena masih dominannya guru dalam praktek pembelajaran, dan penerapan sistem mengajar yang digunakan masih menitik beratkan pada metode konvensional, seperti ceramah dan penugasan yang kurang motivasi, sehingga kurang mampu melibatkan siswa secara aktif dalam proses pembelajaran

\section{Kegiatan Pra Tindakan}

Kegiatan pra tindakan dilakukan dengan berdialog antara peneliti bersama kolaborator mata pelajaran bahasa Inggris ibu Tri Hartanti, S.Pd dan kepala sekolah ibu Endri Suwartini, kami berdiskusi tentang kompetensi siswa dalam pembelajaran bahasa Inggris di SDN Sagan Yogyakarta.

Kegiatan lanjutan dari wawancara antara peneliti dan kolaborator adalah terjunnya peneliti kedalam proses pembelajaran bahasa Inggris di kelas. Pada tahap ini, atas izin kepala sekolah dan guru mata pelajaran bahasa Inggris peneliti mengamati proses pembelajaran yang terjadi di dalam kelas pada hari kamis 10 Januari 2013 yang berlangsung selama 2 x 35 menit atau dua jam pelajaran 
Dari kegiatan pra tindakan peneliti memeroleh nilai hasil ulangan harian bahasa Inggris siswa kelas IV SD Sagan. Hasil nilai ulangan diperoleh dari nilai ulangan harian yang diselenggarakan dikelas pada kamis, 4 April 2013. Hasil ulangan ini diperoleh dari guru bidang studi bahasa Inggris SD Negeri Sagan Yogyakarta. Adapun hasil ulangan tersebut adalah sebagai berikut:

Tabel 3. Ketuntasan Belajar Pra Tindakan

\begin{tabular}{cccccc}
\hline \multirow{2}{*}{$\begin{array}{c}\text { Jumlah } \\
\text { Siswa }\end{array}$} & \multicolumn{4}{c}{ Pra Siklus } & Rata-rata \\
\cline { 2 - 4 } & Ketuntasan & \multicolumn{2}{c}{ Presentase } & $\begin{array}{c}\text { Nilai } \\
\text { Siswa }\end{array}$ \\
\cline { 2 - 4 } & T & BT & T & BT & \\
\hline 25 & 11 & 14 & $44 \%$ & $56 \%$ & 65,40 \\
\hline
\end{tabular}

Hasil Penelitian

Penelitian ini dilaksanakan dengan cara mengikuti alur penelitian tindakan kelas menurut Kemmis \& Taggart. Langkah kerja dalam penelitian ini terdiri dari tahap perencanaan, pelaksanaan tindakan, observasi, dan refleksi. Penelitian ini diterapkan melalui dua siklus di mana satu siklusnya dilakukan dua kali pertemuan. masing-masing pertemuan berdurasi 2 (dua) jam mata pelajaran selama 2 × 35 menit yakni pada jam 09.45 WIB-10.15 WIB.

Siklus I

Penelitian pada Siklus I dilaksanakan dalam dua kali pertemuan, pertemuan pertama dilaksanakan pada tanggai 9 Mei 2013 dengan materi "My Pets". Tindakan pertemuan kedua pada siklus I dilaksanakan seminggu kemudian, yakni pada hari Kamis, 16 Mei 2013 dengan materi yang sama. Selama pembelajaran berlangsung, peneliti dibantu oleh teman sejawat dalam mengadakan pengamatan dengan menggunakan lembar observasi yang telah disiapkan

Berdasarkan hasil tes yang dilaksanakan pada akhir siklus dapat disimpulkan siswa yang memenuhi KKM sebanyak 18 orang dan yang tidak sebanyak 7 orang, secara rinci dapat dilihat pada tabel berikut ;
Tabel 4. Ketuntasan Belajar Siklus I

\begin{tabular}{cccccc}
\hline & \multicolumn{4}{c}{ Siklus I } & Rata-rata \\
\cline { 2 - 4 } $\begin{array}{c}\text { Jumlah } \\
\text { Siswa }\end{array}$ & Ketuntasan & \multicolumn{2}{c}{ Presentase } & $\begin{array}{c}\text { Nilai } \\
\text { Siswa }\end{array}$ \\
\cline { 2 - 5 } & T & BT & T & BT & \\
\hline 25 & 18 & 7 & $72 \%$ & $28 \%$ & 75,12 \\
\hline
\end{tabular}

Dari tabel di atas dapat disimpulkan bahwa banyaknya siswa yang memenuhi KKM adalah sebanyak 18 siswa dengan persentase $72 \%$ dan dengan nilai rata-rata nilai siswa sebesar 75,12 \%. Jumlah ini menandakan adanya peningkatan nilai hasil belajar dari kegiatan sebelum dilakukannya tindakan.

\section{SIklus II}

Pelaksanaan tindakan siklus II pada dasarnya sama dengan tindakan siklus I, yang membedakan adalah adanya perubahan. Perubahan ini ada karena berasal dari hasil refleksi kelemahan-kelemahan pada tindakan siklus I. Pelaksanaan tindakan siklus ke II ini terdiri dari dua kali pertemuan, yaitu pada hari kamis tanggal 23 Mei 2013 dan 30 Mei 2013 dengan materi pelajaran Foods \& Drinks. Berdasarkan hasil tes yang dilaksanakan pada akhir siklus didapat hasil sebagai berikut :

Tabel 5. Ketuntasan belajar siklus II

\begin{tabular}{cccccc}
\hline \multirow{2}{*}{$\begin{array}{c}\text { Jumlah } \\
\text { Siswa }\end{array}$} & \multicolumn{4}{c}{ Siklus II } & \multicolumn{2}{c}{ Kata-rata } \\
\cline { 2 - 5 } & Ketuntasan & \multicolumn{2}{c}{ Presentase } & $\begin{array}{c}\text { Nilai } \\
\text { Siswa }\end{array}$ \\
\cline { 2 - 5 } & T & BT & T & BT & \\
\hline 25 & 23 & 2 & $92 \%$ & $8 \%$ & 83,80 \\
\hline
\end{tabular}

Dari tabel di atas dapat disimpulkan bahwa banyaknya siswa yang memenuhi KKM adalah sebanyak 23 siswa dengan persentase $92 \%$ dan dengan nilai rata-rata nilai siswa sebesar $83,80 \%$. Jumlah ini menandakan adanya peningkatan nilai hasil belajar dari kegiatan sebelum dilakukannya tindakan, dan dari tindakan pada siklus I.

Pembahasan

\section{Observasi Siswa dan Guru dalam Proses Pembelajaran pada Siklus I dan II}

Berdasarkan hasil observasi secara kualitatif, baik pada pembelajaran siklus I dan II menunjukan bahwa siswa sudah mulai menunjukan sikap senang dan aktif dalam belajar. 
Sebagian besar siswa telah mampu bekerjasama dengan baik bersama teman dan kelompoknya, bertanggung jawab pada kegiatan kelompok dan menjalin komunikasi yang baik dengan teman kelompoknya. Dipihak lain, dalam pelaksanaan pembelajaran guru juga telah melaksanakan pembelajaran yang sesuai dengan skenario pembelajaran yang telah direncanakan. Selama proses pembelajaran, guru memotivasi siswa dan membimbing siswa dengan sangat baik. Pengaturan waktu serta pengelolaan siswa ke dalam kelompok juga dilaksanakan dengan baik. Hal tersebut memberikan gambaran bahwa pembelajaran yang berlangsung pada siklus I dan II telah terlaksana dengan baik dan berorientasikan pada tipe TGT.

Hasil observasi secara kuantitatif terhadap penerapan media anagram dalam metode pembelajaran kooperatif tipe $T G T$ ditinjau melalui dua aspek yaitu aktivitas siswa dalam pembelajaran dan aktivitas guru selama proses pembelajaran. Hasil observasi aktivitas siswa dalam pembelajaran pada siklus I dan II adalah sebagai berikut :

Tabel 6 Peningkatan akitivitas siswa

\begin{tabular}{ccccc}
\hline & \multicolumn{2}{c}{ Siklus I } & \multicolumn{2}{c}{ Siklus II } \\
\cline { 2 - 5 } & \multicolumn{2}{c}{ Pertemuan } & \multicolumn{2}{c}{ Pertemuan } \\
\cline { 2 - 5 } & I & II & I & II \\
\hline Jumlah Skor & 14 & 19 & 20 & 20 \\
Jumlah & $70 \%$ & $95 \%$ & $100 \%$ & $100 \%$ \\
Rata-rata & & & & \\
\hline
\end{tabular}

Apabila ditinjau dari aspek aktivitas guru selama proses pembelajaran pada siklus I dan II adalah sebagai mana disajikan pada tabel berikut :

Tabel 7. Peningkatan akitivitas guru

\begin{tabular}{ccccc}
\hline & \multicolumn{2}{c}{ Siklus I } & \multicolumn{2}{c}{ Siklus II } \\
\cline { 2 - 5 } & \multicolumn{2}{c}{ Pertemuan } & \multicolumn{2}{c}{ Pertemuan } \\
\cline { 2 - 5 } & I & II & I & II \\
\hline Jumlah Skor & 16 & 19 & 20 & 20 \\
Jumlah & $80 \%$ & $95 \%$ & $100 \%$ & $100 \%$ \\
Rata-rata & & & & \\
\hline
\end{tabular}

\section{Penguasaan Kosakata Siswa}

Berdasarkan deskripsi keterampilan berbahasa siswa selama pelaksanaan tindakan dari siklus I hingga siklus II sebagaimana telah diuraikan pada bab sebelumnya, maka diketahui bahwa penerapan media anagram dalam metode pembelajaran kooperatif tipe $T G T$ dapat meningkatkan penguasaan kosakata siswa. Yakni kosakata aktif produktif atau kosakata yang sering digunakan yakni meliputi indikator menu- lis dan berbicara. Peningkatan penguasaan kosakata bahasa Inggris siswa dapat dibuktikan dari adanya peningkatan aktivitas siswa dalam pembelajaran dan dari hasil belajar siswa yang terus meningkat pada tiap siklusnya.

Berdasarkan tindakan yang dilaksanakan dalam tiap siklus dapat dilihat adanya peningkatan siswa dalam pembelajaran dan dari hasil belajar siswa yang terus meningkat pada tiap siklusnya. Adapun data peningkatan penguasaan kosakata siswa dapat dilihat pada grafik berikut:

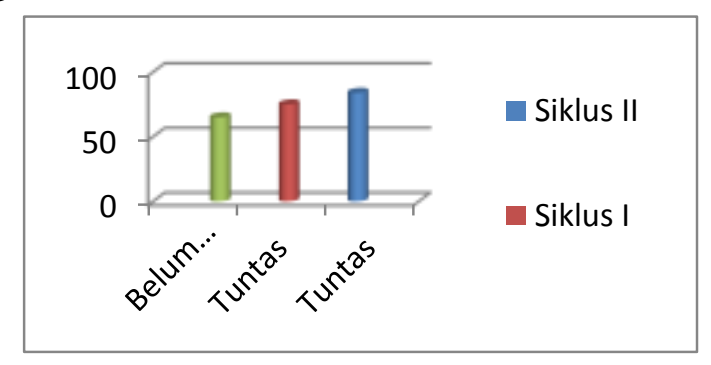

Gambar 2.Grafik Peningkatan Penguasaan

Kosakata Bahasa Inggris Siswa Kelas IV

\section{Simpulan dan Saran}

Berdasarkan hasil pengamatan dan penilaian yang telah dilaksanakan dapat disimpulkan penerapan media anagram dalam metode cooperative learning tipe TGT dapat meningkatkan penguasaan kosakata bahasa Inggris siswa yang ditandai dengan peningkatan hasil belajar siswa, yakni sebelum diberi tindakan rata-rata nilai siswa sebesar $65,40 \%$ dengan jumlah siswa yang tuntas belajar sebanyak 11 (sebelas) orang dari 25 (dua puluh lima) siswa. Kemudian setelah diberi tindakan pada siklus I rata-rata nilai siswa meningkat menjadi 75 , $12 \%$ dengan siswa yang tuntas sebanyak 18 orang, dan peningkatan juga terjadi pada siklus II, yakni dari hasil tes diperoleh rata-rata nilai siswa sebanyak $83.80 \%$.

Mencermati hasil penelitian yang ditemukan, maka saran disampaikan kepada beberapa pihak berikut: (1) Siswa, Penguasaan kosakata siswa dan keaktifan dalam proses pembelajaran sudah meningkat, oleh karena itu perlu dipertahankan; (2) Guru, diharapkan bisa meneruskan proses pembelajaran ini dan menerapkannya dikelas-kelas lain; (3) Pihak Sekolah, penerapan media anagram dalam metode cooperative learing tipe Teams-Games-Tournament (TGT) hendaknya diteruskan oleh sekolah kepada guru-guru bersangkutan pada tema kelas yang lain, untuk pengembangan dan peningkatan mutu sekolah. 


\section{Daftar Pustaka}

Blachowicz, C. \& Fisher, P. (1996) Teaching vocabulary in all classroms. Columbus, Ohio: Englewood Clifs, New Jersey

Djiwandono, S. (2011). Tes bahasa pegangan bagi pengajar bahasa. Malang: Indeks

Johnson, D.W \& Johnson, R.T. (2002). Meaningful assessment; a manageable and cooperatve process. Boston: A Pearson Education Company.
Kridalaksana, H. (2008) Kamus Linguistik. Jakarta: Gramedia

Nurhadi. (1995). Tata bahasa pendidikan. Semarang: IKIP Semarang Press

Slavin. (1995). Cooperative learning, theory, research, and practice. America: United States of America

Tarigan, H. G (2011). Pengajaran kosakata. Bandung: Angkasa 